\title{
Small molecule targeting amyloid fibrils inhibits Streptococcus mutans biofilm formation
}

Yuanyuan Chen ${ }^{1,3}$, Guxin Cui ${ }^{1,3}$, Yuqi Cui ${ }^{1,3}$, Dongru Chen ${ }^{2,3^{*}}$ and Huancai Lin ${ }^{1,3^{*}}$ (D)

\begin{abstract}
Amyloid fibrils are important scaffold in bacterial biofilms. Streptococcus mutans is an established cariogenic bacteria dwelling within biofilms, and $\mathrm{C} 123$ segment of $\mathrm{P} 1$ protein is known to form amyloid fibrils in S. mutans biofilms, among which C3 segment could serve as a promising anti-amyloid target due to its critical role in C123-P1 interactions. Recently, small molecules have been found to successfully inhibit biofilms by targeting amyloid fibrils. Thus, our study aimed to screen small molecules targeting C3 segment with the capacity to influence amyloid fibrils and $S$. mutans biofilms. In silico screening was utilized to discover promising small molecules, which were evaluated for their effects on bacterial cells and amyloid fibrils. We selected 99 small molecules and enrolled 55 small molecules named D1-D55 for crystal violet staining. Notably, D25 selectively inhibit S. mutans biofilms but had no significant influence on biofilms formed by Streptococcus gordonii and Streptococcus sanguinis, and D25 showed no bactericidal effects and low cytotoxicity. In addition, amyloid fibrils in free-floating bacteria, biofilms and purified C123 were quantified with ThT assays, and the differences were not statistically significant in the presence or absence of D25. Morphological changes of amyloid fibrils were visualized with TEM images, where amorphous aggregates were obvious coupled with long and atypical amyloid fibrils. Moreover, amyloid-related genes were upregulated in response to D25. In conclusion, D25 is a promising antimicrobial agent with the capacity to influence amyloid fibrils and inhibit S. mutans biofilms.
\end{abstract}

Keywords: Amyloid fibrils, Streptococcus mutans, Biofilm formation, Small molecule

\section{Introduction}

Biofilms are complex microbial aggregates that are widely distributed in diverse environment (Flemming and Wingender 2010). In robust biofilms, bacterial cells show enhanced resistance to antibiotics, environmental insults and host defenses than free-floating bacterial cells (Costerton et al. 1999; Flemming and Wingender 2010). As a consequence, biofilms are difficult to eradicate and would result in chronic infections. Thus, it is of great importance to find antibiofilm agents that can prevent biofilm formation and ultimately reduce biofilm infections.

\footnotetext{
*Correspondence: chendr6@mail.sysu.edu.cn; linhc@mail.sysu.edu.cn 1 Department of Preventive Dentistry, Hospital of Stomatology, Sun Yat-Sen University, Guangzhou, Guangdong, China

2 Department of Orthodontics, Hospital of Stomatology, Sun Yat-Sen

University, Guangzhou, Guangdong, China

Full list of author information is available at the end of the article
}

Multiple determinants involve in the development and formation of bacterial biofilms, and they vary in different species and environmental conditions (Cegelski et al. 2009; Romero et al. 2010). Nevertheless, polysaccharide, proteins and extracellular DNA are commonly occurring parts, and extracellular polysaccharide have been wellstudied for its crucial role affecting pathogenesis (Cegelski et al. 2009; Romero et al. 2010; Bowen and Koo 2011). Recently, another important matrix component variously known as amyloid fibrils seems to be attractive, and has been reported in numerous studies that involves in the biofilm formation of many bacterial species (Larsen et al. 2007). The foremost studied amyloid fibrils are the curli fibers in Escherichia coli and Salmonella species, which biophysically and biochemically polymerize into pathogenic amyloids and participate in biofilm formation (Chapman et al. 2002; Saldaña et al. 2009; Erskine 
et al. 2018). Emerging studies on phenol-soluble modulins (PSMs) in Staphylococcus aureus and TasA fibers in Bacillus subtilis also reveal the importance of amyloid fibrils in biofilm formation (Erskine et al. 2018). The general hallmark of amyloid fibrils in biofilms is their role as protein scaffold to mediate interactions between bacteria and extracellular matrix or interactions with other extracellular components (Jong et al. 2009; Blanco et al. 2012; Loquet et al. 2018). Moreover, they benefit in adhesion to surface and changing surface properties as well as stabilizing the biofilms (Blanco et al. 2012). Due to the vital role of amyloid fibrils in biofilm development, amyloid inhibitors designed have been intensively developed and reported. For instance, $\alpha$-sheet peptides are potential inhibitors for $S$. aureus biofilms by preferential binding to $\alpha$-sheet structure of PSM $\alpha 1$ (Bleem et al. 2017). Additionally, D-peptides, originally designed to inhibit oligomers of amyloid- $\beta$ in Alzheimer's disease, target CsgA spine segments to inhibit CsgA fibrillation and finally reduce Salmonella typhimurium biofilm (Perov et al. 2019). In conclusion, targeting amyloid-forming proteins to inhibit fibrillation would be helpful in addressing biofilm-related diseases (Perov et al. 2019).

A paradigm of amyloid fibrils in Gram-positive organisms is emerging in researches for Streptococcus mutans, where amyloid fibrils are biofilm-related issues (Besingi et al. 2017). S. mutans is well-known as an established cariogenic agent, dwelling on tooth surface within biofilms to cause dental caries (Lemos et al. 2019). Amyloid fibrils are visualized ubiquitously in both clinical and laboratory strains of $S$. mutans (Oli et al. 2012). Of note, P1, also named Antigen I/II, SpaP, AgB or PAc, is initially identified as a representing amyloid-forming protein in S. mutans, where C123 (C-terminal segment) of $\mathrm{P} 1$ protein is liberated separately and associates with cell-wall anchored P1 in a non-covalently way to form functional supramolecular structure regarded as amyloid fibrils (Brady et al. 2010; Larson et al. 2011; Oli et al. 2012; Heim et al. 2014, 2015; Besingi et al. 2017). More recently, biological interactions of C3 with A3VP1 (a globular region in $\mathrm{P} 1$ ) unravel that $\mathrm{C} 3$ fragment serves as foundation during C123-P1 interactions (Rivière et al. 2020). The interactions between $C 123$ and $P 1$ also likely contribute to biofilm-related events such as formation of amyloid fibrils by C123 (Rivière et al. 2020), suggesting that $\mathrm{C} 3$ would serve as a promising anti-amyloid target.

Managing dental caries with amyloid inhibitors, such as $\alpha$-sheet peptides, are reported to be promising (Paranjapye and Daggett 2018). Apart from peptides as antiamyloid agents, small molecules are also a rich source to need great demand for therapeutics that disperse $S$. mutans biofilms through non-microbicidal pathways (Scharnow et al. 2019). Small molecules are convenient for manufacture and can target proteins specifically that other drugs are unable to access, contributing to better curative effects with low adverse effects as well as drug resistance (Chen et al. 2019b). Various approaches have been proposed to select active molecules based on specific targets, and one reliable solution is to find new indications for existing drugs, which is a costless and fast way with a comprehensive drug library (Chong and Sullivan 2007). AA-861, targeting amyloid fibrils to inhibit both S. mutans and B. subtilis biofilms, has been screened successfully from a collection containing 480 small molecules, suggesting that screening small molecules is a novel and feasible strategy to manage biofilm-related events (Romero et al. 2013; Besingi et al. 2017).

Nevertheless, there are few researches about finding small molecules targeting specific amyloid-forming proteins and evaluating their effects on $S$. mutans biofilms. Here, we hypothesize that C3 segment can serve as a specific target for screening small molecules to impede the formation of amyloid fibrils and S. mutans biofilms. Inspired by rapid development of computational technology, we firstly screened for the most potent small molecule and evaluated its antimicrobial effects as well as found its potential mechanism. Based on our results, we could conclude that small molecule was applicable in reducing $S$. mutans biofilm through anti-amyloid mechanism, which also proved the effectiveness of amyloid fibrils as targets and will finally benefit in discovering new drugs for prevention and treatment of dental caries.

\section{Materials and methods}

\section{In silico structure-based virtual screening}

MOE (Molecular operating environment) software was utilized for in silico structure-based virtual screening. The crystal structure of $\mathrm{C} 123$ was obtained from Protein Data Bank (PDB, accession number 3QE5) (Burley et al. 2021), and C3 segment in C123 were used to serve as the target protein for screening. Binding energy of C3 segment and small molecules which were collected from Specs database (http://www.specs.net) was calculated within the predicted binding pocket to find promising small molecules with drug-like properties based on Lipinski's rules (Detailed procedure was posted in Materials and Methods part in Additional file 1). Top 99 small molecules with the highest binding energy were selected, among which 94 small molecules were purchased from Specs Company (Delft, Netherlands). Fifty-five small molecules which could dissolved in DMSO at $10 \mathrm{mg} / \mathrm{mL}$ were named D1-D55 and were enrolled in further experiments. For all assays, the final concentration of DMSO was set at $1 \%$, and wells with $1 \%$ DMSO were set as the control group. 


\section{Bacterial strains and culture conditions}

Bacterial strains, including S. mutans UA159 (ATCC 700610), Streptococcus sanguinis (ATCC 10556), Streptococcus gordonii (DL-1) were grown statically in BHI broth (brain heart infusion, Difco, USA) at $37{ }^{\circ} \mathrm{C}$ under anaerobic conditions $\left(10 \% \mathrm{H}_{2}, 5 \% \mathrm{CO}_{2}, 85 \%\right.$ $\mathrm{N}_{2}$ ), and adjusted to $1 \times 10^{6} \mathrm{CFU} / \mathrm{mL}$ through all the experiments.

\section{Biofilm formation assay}

Biomass of $S$. mutans biofilms was calculated through crystal violet staining for preliminary screening as described before with some modifications (Zhang et al. 2019). Noticeably, BHIs (brain heart infusion with $1 \%$ sucrose) was applied to trigger formation of biofilms as reported previously where amyloid inhibitors are still effective when $S$. mutans forms biofilm in sucrose-rich medium (Besingi et al. 2017). Briefly. S. mutans were grown statistically and anaerobically in BHIs broth containing small molecules from 6.25 to $100 \mu \mathrm{g} / \mathrm{mL}$ to a total of $200 \mu \mathrm{L}$ in 96 -well plates. After $24 \mathrm{~h}$, biofilms were washed 3 times with phosphate-buffered saline (PBS) to remove unbound bacteria and fixed with absolute methanol for at least $15 \mathrm{~min}$. Fixed biofilms were then stained with $0.1 \%$ crystal violet solution for $15 \mathrm{~min}$, followed by gentle washing with flowing water until no existing dye appeared in blank wells. Once no visible water was detected in wells, $200 \mu \mathrm{L}$ of $95 \%$ ethanol was added and plates were shaken vigorously for 30 min to solubilize biofilms. Finally, solubilization was transferred to new 96-well plates to denote the absorbance at $595 \mathrm{~nm}$. Three independent experiments were conducted to get final biomass. Most potent small D20 and D25 were selected from preliminary screening and enrolled in future investigations. The effects of D20 and D25 on S. mutans, S. gordonii and S. sanguinis biofilms from 1.56 to $25 \mu \mathrm{g} / \mathrm{mL}$ were measured by crystal violet staining in the same manner as described above.

\section{CFU counts}

The bactericidal effects of D20 and D25 at the concentration of $1.56-25 \mu \mathrm{g} / \mathrm{mL}$ were evaluated using CFU counts as described previously (Chen et al. 2021). S. mutans, S. gordonii and S. sanguinis cells were inoculated into BHI broth with or without small molecules in $1.5 \mathrm{~mL}$ Eppendorf tubes. After $24 \mathrm{~h}$, the solution was serially diluted ten-fold to $10^{6}$ fold with PBS, and $10 \mu \mathrm{L}$ was pipetted and placed on BHI agar plate at $37{ }^{\circ} \mathrm{C}$ anaerobically for $36 \mathrm{~h}$ (Chen et al. 2021). CFU counts were determined with three independent experiments.

\section{Cytotoxicity assay of HGE cells (human gingival epithelial} cells)

Cell viability was evaluated with a cell counting kit-8 (Chen et al. 2021). HGE cells were firstly seeded in 96-well plates $(3000$ cell/100 $\mu \mathrm{L})$ for $24 \mathrm{~h}$, and then treated with medium containing $1 \%$ DMSO or medium with D20 or D25 $(1.56-25 \mu \mathrm{g} / \mathrm{mL})$. After incubation for another 24, 48 and $72 \mathrm{~h}$, cells were washed with PBS and fresh medium $(100 \mu \mathrm{L})$ with CCK-8 $(10 \mu \mathrm{L})$ was added. The plates were incubated for another $1 \mathrm{~h}$ and were measured at $\mathrm{OD}_{450}$, and the cell viability was finally calculated with three independent experiments according to the manufacturer's instructions (DojinDo, Japan).

\section{Biofilm imaging}

S. mutans cells were seeded on sterile glass coverslips for $24 \mathrm{~h}$ to form biofilms with or without the addition of D25 at a final concentration of $6.25 \mu \mathrm{g} / \mathrm{mL}$. The biofilms were then visualized by different microscopies. Confocal laser scanning microscopy (CLSM) was performed to record the distribution of live/dead bacteria and $3 \mathrm{D}$ architecture within biofilms. S. mutans biofilms were incubated on glass coverslips in 48-well plates and then rinsed with $\mathrm{dd}_{2} \mathrm{O}$ to remove free-floating cells. Biofilms were then stained with $2.5 \mu \mathrm{M}$ SYTO 9 and propidium iodide (Invitrogen, USA) as described previously (Klein et al. 2009; Ren et al. 2016; Chen et al. 2021), and imaged using CLSM with a $63 \times$ lens objective (Zeiss, Germany). The three-dimensional structure was documented and quantified using COMSTAT image-processing software (Heydorn et al. 2000; Klein et al. 2009; Ren et al. 2016). For scanning electron microscopy (SEM) studies, biofilms were formed as shown in CLSM assays. Differently, biofilms were fixed with $2.5 \%$ glutaraldehyde for at least $3 \mathrm{~h}$, dehydrated using graded ethanol (30-100\%), treated with tert-butanol for three times and afterwards, freezedried and sputtered with gold. Images were recorded using SEM system (FEI, QUANTA2000, Czech Republic). Atomic force microscopy (AFM) was utilized to portray the morphology of single bacterial cells in biofilms as described previously (Sharma et al. 2014). After incubation on sterile coverslips in 12-well plates for $24 \mathrm{~h}$, the medium was decanted and the biofilms were immersed in PBS for observation by AFM with tapping-mode (Bruker, USA).

\section{Quantification analysis and TEM images of bacterial amyloid fibrils}

S. mutans cells were grown in BHI broth with $1 \%$ DMSO or BHI broth with $6.25 \mu \mathrm{g} / \mathrm{mL}$ D25 to quantify amyloid fibrils with ThT (Thioflavin $\mathrm{T}$ ) fluorescence assays. ThT could bind to $\beta$-sheet structures in amyloid fibrils 
specifically and ThT assay is regarded as the gold standard to explore the formation of amyloid fibrils, where the intensity of ThT could reflect the quantification of amyloid fibrils (LeVine 1999; Bleem et al. 2017; Paranjapye and Daggett 2018). Free-floating bacteria were incubated anaerobically at $37^{\circ} \mathrm{C}$ in $1.5 \mathrm{~mL}$ Eppendorf tubes for $24 \mathrm{~h}$. Then the bacterial cells were harvested by centrifugation $\left(12,000 g, 10 \mathrm{~min}, 4{ }^{\circ} \mathrm{C}\right)$ and resuspended with PBS. PBS with $1 \%$ DMSO was set as the blank control. Samples were mixed with $40 \mu \mathrm{M}$ ThT in equal volume and the mixture was pipetted into opaque 96 -well plates. Plates were incubated for $15 \mathrm{~min}$, and fluorescence intensity was measured at $438 \mathrm{~nm}$ excitation and $495 \mathrm{~nm}$ emission (Romero et al. 2010; Schwartz et al. 2012, 2016). Fluorescence intensity was modified by subtracting intensity of blank control. Additionally, samples were imaged via TEM to depict the structure of amyloid fibrils as stated previously (Schwartz et al. 2012). Briefly, samples were absorbed onto formvar-coated copper grides, stained with 3\% phosphotungstic acid for 2 min and washed with sterile $\mathrm{ddH}_{2} \mathrm{O}$. TEM images were recorded through Hitachi TEM system. Moreover, ThT fluorescence was also measured in S. mutans biofilms with some modifications (Chen et al. 2019a). S. mutans biofilms were firstly incubated in 6-well plates for $24 \mathrm{~h}$ in same conditions as described above. Then samples were scrapped, resuspended with PBS and mixed with ThT to obtain fluorescence intensity. Simultaneously, samples were prepared for TEM images to depict morphology of amyloid fibrils in S. mutans biofilms.

\section{Fibrilization of purified $\mathrm{C} 123$ in vitro}

ThT assays were also applied to explore the effects of D25 on amyloid-forming protein $\mathrm{C} 123$. At the very beginning, we got access to purified $\mathrm{C} 123$ with the same protocols as reported previously (Chen et al. 2019a). Protein was diluted with PBS to $0.1 \mathrm{mg} / \mathrm{mL}$ and mixed with PBS with $1 \%$ DMSO or PBS with D25 at $6.25 \mu \mathrm{g} / \mathrm{mL}$, then the mixture in $1.5 \mathrm{~mL}$ Eppendorf tubes was stirred at $4{ }^{\circ} \mathrm{C}$ for $72 \mathrm{~h}$ (Besingi et al. 2017). ThT fluorescence were measured in the presence or absence of purified protein, and final ThT fluorescence were calculated by subtracting ThT fluorescence without protein. Moreover, samples were also prepared for TEM imaging as described above.

\section{Gene expression}

Quantitative reverse transcriptase PCR (qRT-PCR) was used to evaluate the effects of D25 on the expression levels of amyloid-related genes. Biofilms were grown with BHIs broth in 6-well plates in the presence or absence of D25 at $6.25 \mu \mathrm{g} / \mathrm{mL}$. After $24 \mathrm{~h}$, biofilms were scraped, centrifugated $\left(12,000 \mathrm{~g}, 10 \mathrm{~min}, 4{ }^{\circ} \mathrm{C}\right)$ and harvested into $1.5 \mathrm{~mL}$ Eppendorf tubes. The bacterial cells were lysed with $500 \mu \mathrm{L}$ lysis buffer ( $20 \mathrm{mg} / \mathrm{mL}$ lysozyme; $20 \mathrm{Mm}$ Tris- $\mathrm{HCl}, \mathrm{PH}=8 ; 2 \mathrm{mM}$ EDTA; $1.2 \%$ Triton) for at least $2 \mathrm{~h}$ and treated with proteinase $\mathrm{K}$ for at least $30 \mathrm{~min}$. RNA was extracted from lysate using manufacturer' protocols. The purification of the lysate was determined using Nanodrop 2000 (Thermo Fisher, USA) followed by reversetranscription of interest RNA. Comparative expression of genes were ultimately quantified according to the $2^{-\Delta \Delta \mathrm{CT}}$ method (Detailed procedure was posted in Materials and Methods part in Additional file 1: Table S1).

\section{Statistical analysis}

Data are mean \pm standard deviations from three independent experiments. Statistical analysis of all data were performed with GraphPad Prism 7 (GraphPad Software, San Diego, USA) using analysis of variance (ANOVA) and Student's two-sample $t$ test. Dunnett's multiple comparison were used to compare differences between control group and treated group. Significant differences were set at the $95 \%$ confident level.

\section{Results \\ Preliminary structure-based virtual screening for finding potent small molecules}

Based on Specs database, we conducted structure-based virtual screening method to find small molecules with higher docking scores with C3. The crystal structure of C3 in C123 were obtained from Protein Data Bank and utilized in the screening. Totally, we screened about 2,20,000 small molecules and listed top 99 small molecules (Additional file 1: Figure S1). We purchased 94 small molecules with enough mass from Specs company, and 55 small molecules were dissolved in DMSO to get stocking solution, which were then diluted into gradient concentrations and finally enrolled in the crystal staining assay (Additional file 1: Table S2; Fig. 1). Notably, initial concentrations were set for D20, D55 at $50 \mu \mathrm{g} / \mathrm{mL}$ and D25 at $25 \mu \mathrm{g} / \mathrm{mL}$ respectively, owing to their solubility when added into different mediums.

According to our results, small molecules D1, D6, D8, D21, D24, D28, D32, D34 and D55 showed inhibitory effects against $S$. mutans biofilms at higher concentrations (more than $6.25 \mu \mathrm{g} / \mathrm{mL}$ ). At lower concentrations $(6.25 \mu \mathrm{g} / \mathrm{mL})$, only D20 and D25 corroborative showed inhibitory effects on biofilms (Fig. 1). Thus, we recruited D20 and D25 for detailed investigations.

\section{Better performance of D25 on S. mutans biofilms, free-floating bacteria and cytotoxicity}

In light of strong antibiofilm effects of D20 and D25 at the concentration of $6.25 \mu \mathrm{g} / \mathrm{mL}$, we wondered whether they would function at lower concentrations. We then evaluated D20 and D25 for antibiofilm and bactericidal 

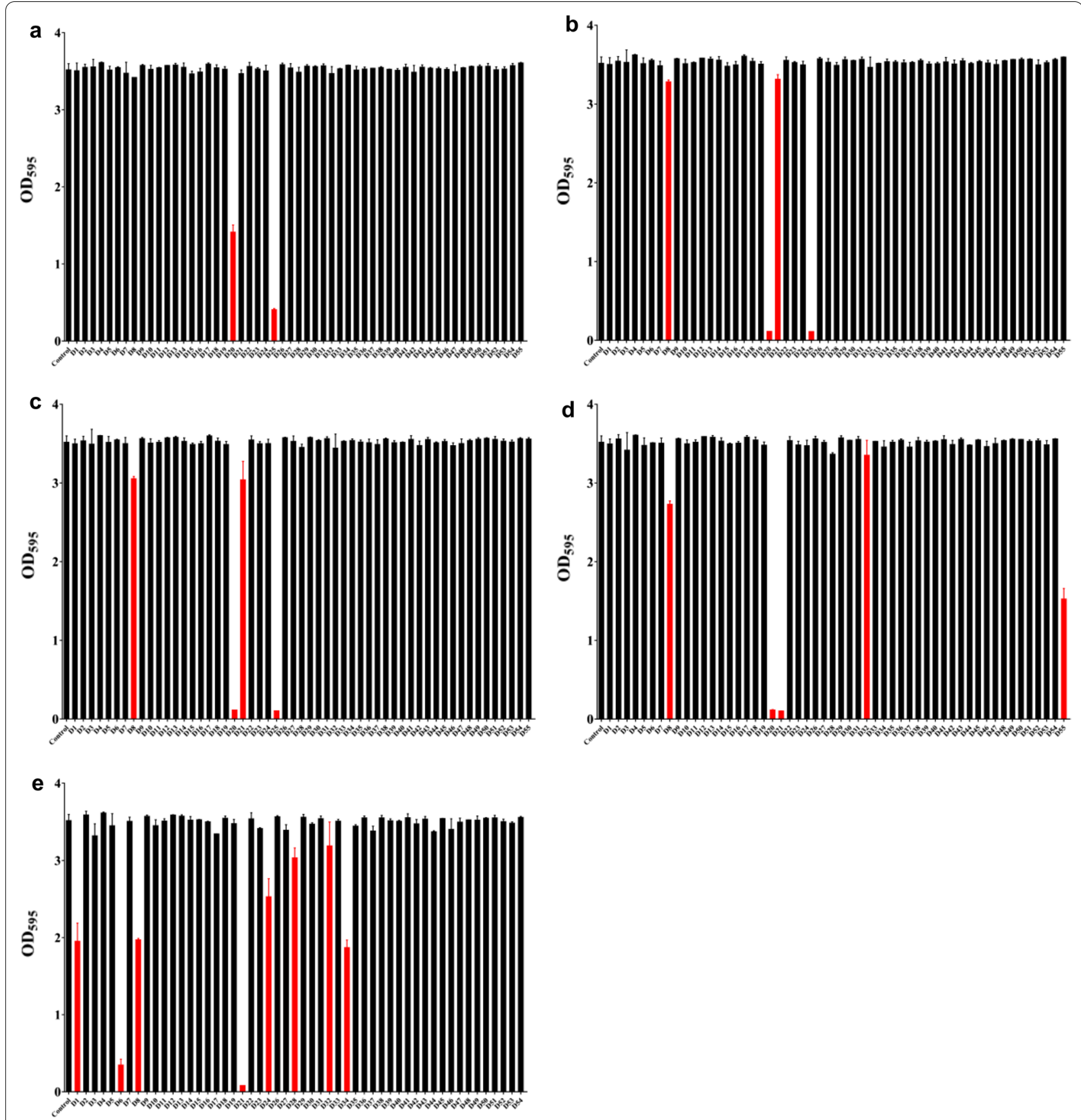

Fig. 1 Effects of compounds at a $6.25 \mu \mathrm{g} / \mathrm{mL}$, b $12.5 \mu \mathrm{g} / \mathrm{mL}, \mathbf{c} 25 \mu \mathrm{g} / \mathrm{mL}$, d $50 \mu \mathrm{g} / \mathrm{mL}$ and e $100 \mu \mathrm{g} / \mathrm{mL}$ on S. mutans biofilm were evaluated in vitro by crystal violet staining. Data are mean \pm standard deviations from three independent experiments. The red bars denoted that differences of biomass in control and these groups were statistically significant $(P<0.05)$

effects on S. mutans, S. gordonii and S. sanguinis as well as cytotoxicity at the concentration of $1.56-25 \mu \mathrm{g} / \mathrm{mL}$. Effects of D20 and D25 on S. mutans, S. gordonii and S. sanguinis biofilms from 1.56 to $25 \mu \mathrm{g} / \mathrm{mL}$ were demonstrated by crystal violet assay (Fig. 2). It was obvious that D25 had inhibitory impacts on S. mutans biofilms at the concentration of $3.125-25 \mu \mathrm{g} / \mathrm{mL}$, in addition, at $6.25-$ $25 \mu \mathrm{g} / \mathrm{mL}$, D25 inhibited more than 50\% S. mutans biofilms. Nevertheless, biofilms formed by $S$. gordonii and $S$. sanguinis were not impaired in the presence of D25. For D20, it inhibited S. mutans biofilms at the concentration of $6.25-25 \mu \mathrm{g} / \mathrm{mL}$. Unlike D25, D20 tended to show more 

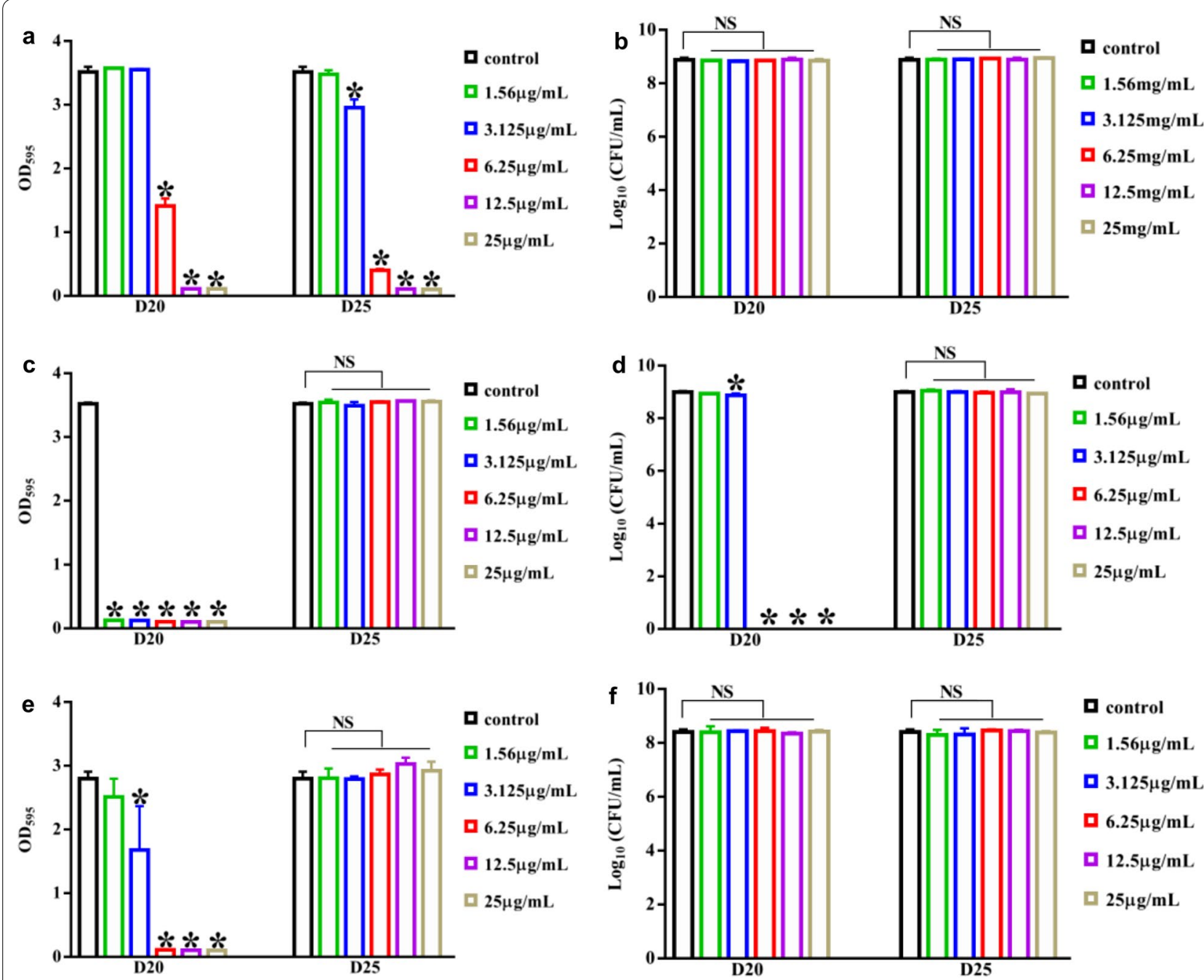

Fig. 2 Effects of D20, D25 on S. mutans, S. gordonii, S. sanguinis biofilms as well as their free-floating bacterial cells. All experiments were conducted at the concentration of $1.56-25 \mu \mathrm{g} / \mathrm{mL}$. Effects on S. mutans, S. gordonii, S. sanguinis biofilm was evaluated by crystal violet staining. a S. mutans biofilm, c S. gordonii biofilm, e S. sanguinis biofilm. Data are mean \pm standard deviations from three independent experiments. Effects of D20 and D25 on free-floating bacterial cells were measured by means of CFU counts. b S. mutans, $\mathbf{d}$ S. gordonii, f S. sanguinis. Data were mean \pm standard deviations from three independent experiments. *Differences were statistically significant when compared with control group $(P<0.05)$. NS differences were not statistically significant when compared with control group

inhibitory effects against $S$. gordonii biofilms from 1.56 to $25 \mu \mathrm{g} / \mathrm{mL}$ and S. sanguinis biofilms from 3.125 to $25 \mu \mathrm{g} /$ $\mathrm{mL}$ respectively. Furthermore, for their effects on freefloating cells, D25 did not impacted S. mutans, S. gordonii and $S$. sanguinis cells at the concentration of $1.56-25 \mu \mathrm{g} /$ $\mathrm{mL}$. On the contrary, D20 presented selective bactericidal effects against $S$. gordonii cells at the concentration of $3.125-25 \mu \mathrm{g} / \mathrm{mL}$, but did not show bactericidal effects on other two streptococci (Table 1; Fig. 2).

Cytotoxicity is also an important property when considered future application. Cell viability was documented on HGE cells for 24-72 h (Fig. 3). D25 did not showed inhibitory effects on cell proliferation at tested
Table 1 Minimum concentration of tested small molecules ( $\mu \mathrm{g} /$ $\mathrm{mL}$ )

\begin{tabular}{llllll}
\hline Bacteria & \multicolumn{2}{l}{ Biofilms } & & \multicolumn{2}{l}{ Free-floating cells } \\
\cline { 2 - 3 } & D20 & D25 & & D20 & D25 \\
\hline S. mutans & 6.25 & 3.125 & & - & - \\
S. gordonii & 1.56 & - & & 3.125 & - \\
S. sanguinis & 3.125 & - & & - & - \\
\hline
\end{tabular}

concentration for $24 \mathrm{~h}(P>0.05)$, but inhibited cell viability at $12.5-25 \mu \mathrm{g} / \mathrm{mL}$ for $48 \mathrm{~h}$ and $72 \mathrm{~h}(P<0.05)$. While D20 inhibited the growth of HGE cells at 12.5-25 $\mu \mathrm{g} /$ 

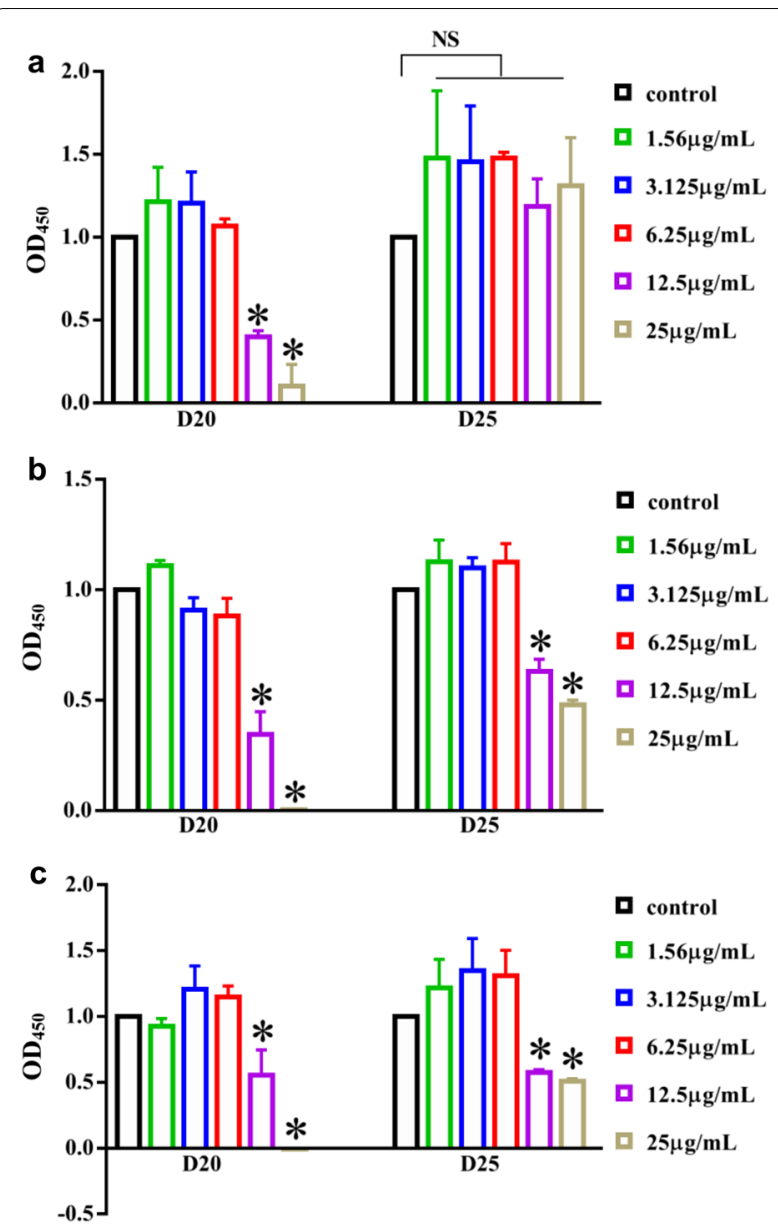

Fig. 3 Cytotoxicity of D20 and D25 on HGE cells. a 24 h, b 48 h and $\mathbf{c} 72 \mathrm{~h}$. Data were mean \pm standard deviations from three independent experiments. *Differences were statistically significant when compared with control group $(P<0.05)$. NS differences were not statistically significant when compared with control group

$\mathrm{mL}$ from 24 to $72 \mathrm{~h}(P<0.05)$. In all, we concluded that D25 showed selectively inhibitory capacity on $S$. mutans biofilms when compared with other two streptococci. Simultaneously, D25 did not influence the growth of freefloating bacterial cells and HGE cells at $1.56-6.25 \mu \mathrm{g} / \mathrm{mL}$. Combined with the inhibitory efficacy of D25 on biofilms, we recruited D25 at the concentration of $6.25 \mu \mathrm{g} /$ $\mathrm{mL}$ for detailed experiments. The chemical structure of D25 and its predicted binding mode with C3 were shown in (Fig. 4).

\section{Morphological changes of S. mutans biofilms}

It was an efficient way to utilize electronic microscopies for sake of recording visual changes. In this study, we applied confocal laser scanning microscopy (CLSM), scanning electron microscopy (SEM) and atomic force microscopy (AFM) to portray morphological changes of
S. mutans biofilms. Firstly, we applied CLSM to record the biofilm in the presence or absence of D25 (Fig. 5a). It was evident that the biofilm was impeded when treated with D25. Simultaneously, the biomass in D25 group was markedly decreased than in control group $(P<0.05)$ (Fig. 5b). Next, SEM was used to recorded inner changes of structure in $S$. mutans biofilms. There was no obvious changes in the shape and size of bacterial cells in D25 group. In addition, all the bacterial cells linked and connected closely to form complex structure (Fig. 5c). Furthermore, the morphology of single bacterial cell in biofilms was recorded via atomic force microscopy (AFM) (Fig. 5d). The shape of the bacterial cells in the treated group was identical to it in control group, which corresponded to the nonfatal properties of D25 as described above.

\section{Antibiofilm activities via amyloid-dependent mechanism}

To elucidate the mechanism of D25 for their antibiofilm ability, we quantified amyloid fibrils by means of ThT assays, and depicted their morphological changes through transmission scanning microscopy (TEM), ultimately we evaluated the transcription level of several related genes to describe the mechanism more detailly. At the very beginning, the effects of D25 on amyloid fibrils in free-floating bacterial cells and in biofilms were investigated via ThT assays quantitatively (Fig. 6a, b). According to our data, we found that ThT uptake of amyloid fibrils in free-floating cells and in biofilms were reduced in the presence of D25, but the differences were not statistically significant compared with control group $(P>0.05)$.

Moreover, considering the importance of confirming morphological changes in amyloid fibrils, TEM was utilized to identify the structure with D25 added (Fig. 6c). Generally, in the absence of antibiofilm agents, amyloid fibrils would be atypical with few amount in the freefloating bacterial cells as described previously (Chen et al. 2019a). Interestingly, in response to D25, morphological changes were obvious due to the occurrence of amorphous aggregates especially in free-floating bacterial cells. These amorphous aggregates were not definitive structures of amyloid fibrils and could not be found in the absence of D25. Amorphous aggregates arranged irregularly to separate amyloid fibrils from cell surface. Furthermore, fibrous structures around amorphous aggregates were long, scattered and apparent (Fig. 6c), differed from typical amyloid fibrils in biofilms (Fig. 6d). In biofilms, bacterial cells were surrounded by dense and numerous amyloid fibrils as described previously (Chen et al. 2019a). In addition, when treated with D25, only a small number of amorphous clusters were detected around the cell surface (Fig. 6d), and they were harder 


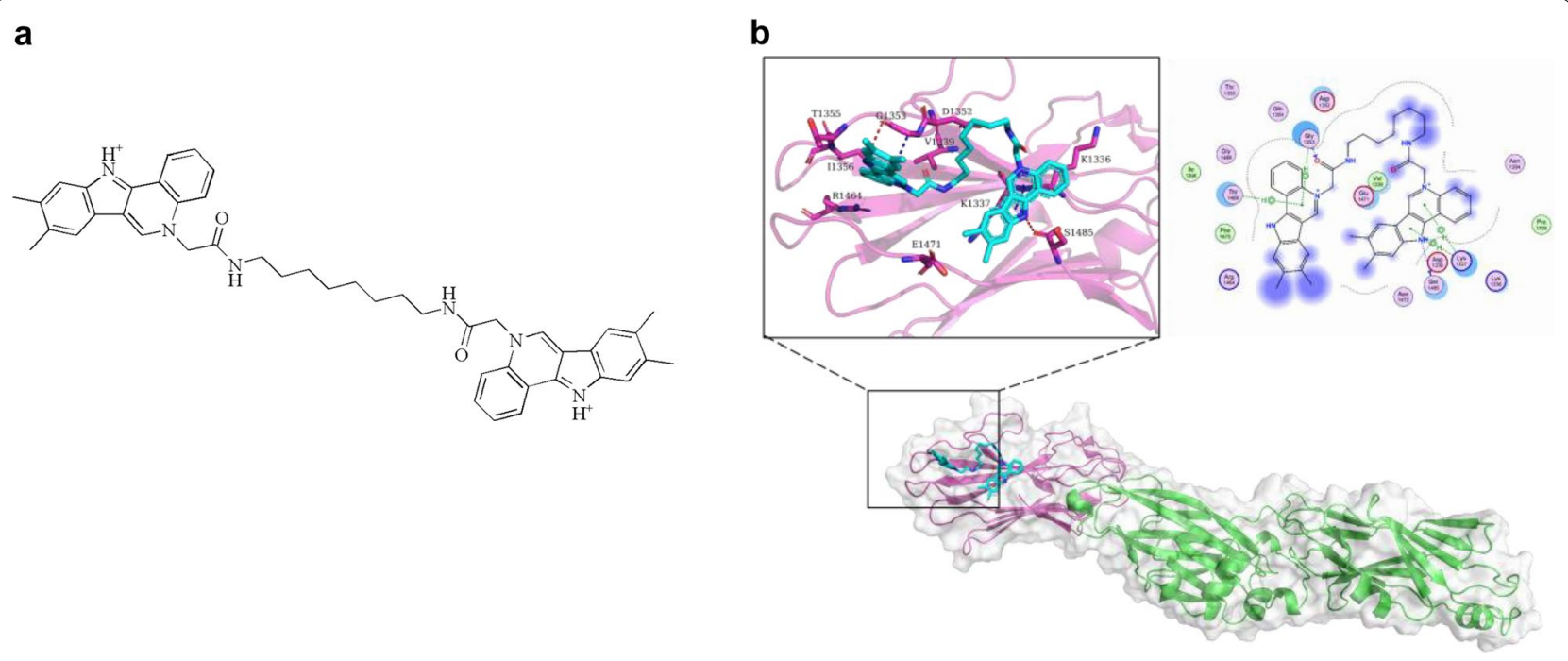

Fig. 4 a The chemical structure of D25. b The binding mode and binding site of D25 with C3

to find than in free-floating bacterial cells. However, this did not indicate the reduction of amorphous aggregates in S. mutans biofilms, but it was likely that amorphous aggregates were shed underneath ascribe to the large number of amyloid fibrils. Besides, it was unique that in some regions, fibrillar structure were liberated away from cell surface, along with single and disperse bacteria without amyloid fibrils (Fig. 6e), which could not be detected in control group. Thus, to some extent, in the presence of D25, morphological changes in amyloid fibrils were obvious and meaningful for us to clarify the underneath mechanism.

To verify the effects of D25 on C123 fragments for their ability to form amyloid fibrils, we synthesized C123 fragments in vitro as mentioned before (Chen et al. 2019a). Purified C123 fragments were mixed with or without small molecules and stirred at $4{ }^{\circ} \mathrm{C}$ for 3 days. Interestingly, there was no reduction in ThT fluorescence with D25 treatment $(P>0.05)$ (Fig. 7a). For TEM images, we found typical amyloid fibrils (about $55 \mathrm{~nm}$ ) in control groups (Fig. 7b) as reported previously (Besingi et al. 2017; Chen et al. 2019a). Notably, amorphous aggregates were obvious in D25 treated group, surrounded by dense amyloid fibrils (Fig. 7b). Hereinto, amorphous aggregates ranged in shape and size in different regions. Coupled amyloid fibrils were long but less wider (about $24 \mathrm{~nm}$ ) compared with typical amyloid fibrils, and interestingly, they were extended from amorphous aggregates at different directions.

Finally, quantitative reverse transcriptase PCR (qRTPCR) was applied to quantify the expression levels of P1 related srtA and pacR genes with D25 added (Fig. 8). The presence of D25 upregulated the transcription level of $\operatorname{srt} A$ gene by about 2.7 -fold $(P<0.05)$. Simultaneously, the expression level of pacR gene was upregulated by about 5.7 -fold $(P<0.05)$.

\section{Discussion}

Due to the vital role of $S$. mutans biofilm formation in dental caries, targeting biofilm-related factors will facilitate discovery and application of new anticaries compounds (Cegelski et al. 2009; Oli et al. 2012). It has been proposed that $S$. mutans biofilms would be inhibited with several amyloid inhibitors (Oli et al. 2012), suggesting a novel antibiofilm strategy in amyloid-dependent way. Thus, in this study, we aimed to find potential inhibitors targeting amyloid-forming proteins with the capacity to reduce $S$. mutans biofilm formation and ultimately benefit in the prevention and treatment of dental caries.

In light of our results, we could conclude that the selected small molecule D25 was reliable and promising as antibiofilm agents. Unlike the broad antibiofilm effects of D20 on S. mutans, S. gordonii and S. sanguinis, which would function by means of bactericidal effects or in other pathways without destroying bacterial cells, the selectivity of D25 would be an advantage for its future application, as D25 did not affect the growth and biofilm formation of S. gordonii and S. sanguinis, and this may account for the specific and unique sequence of $\mathrm{C} 3$ domain used in screening. Virtual screening, which is an effective computational methodology aided in the discovery of new drugs, were utilized in this study (Baig et al. 2016; Ghislat et al. 2021; Kimber et al. 2021; Zorn et al. 2021). Generally, structural information of protein is the core of computational virtual screening that variations in crystal structures would result in different binding 


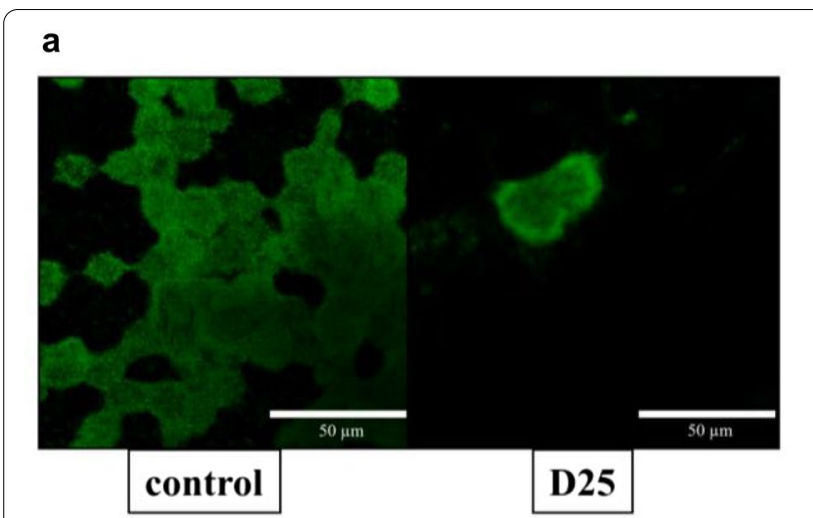

C

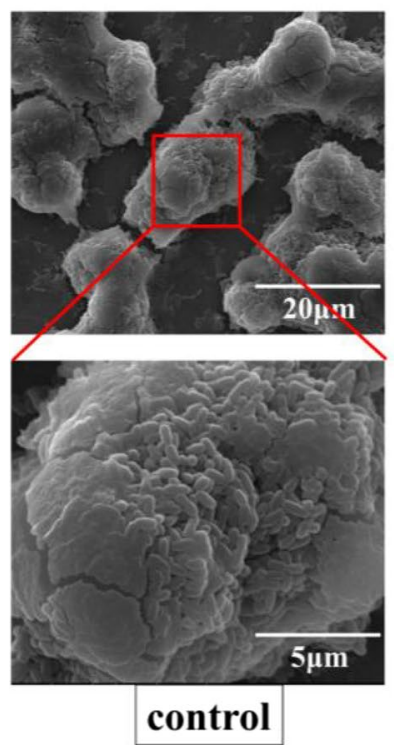

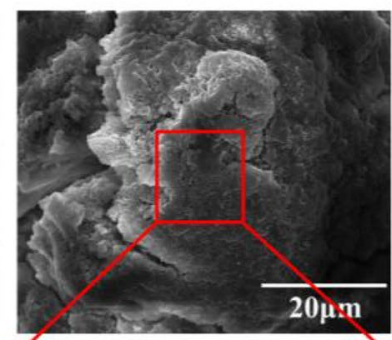

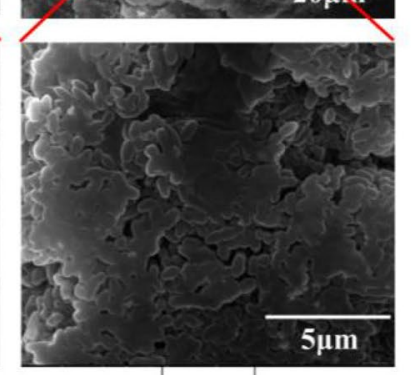

D25 b

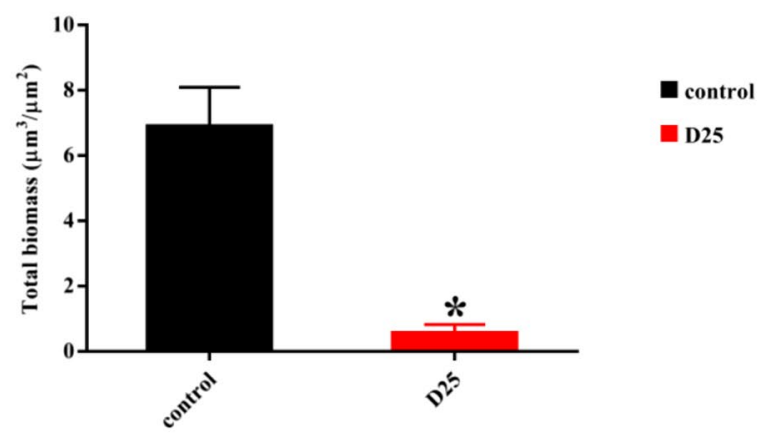

d

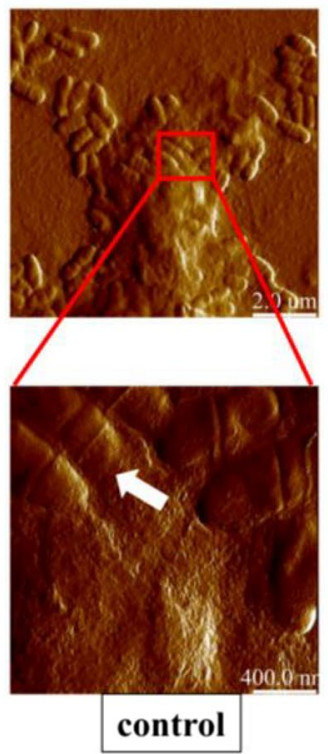

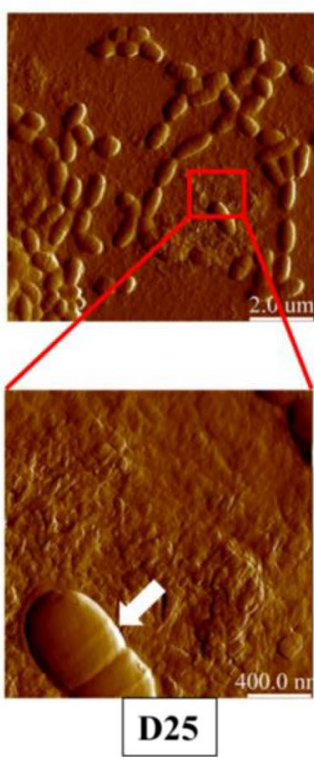

Fig. 5 Morphological changes of S. mutans biofilms when treated with or without D25 at the concentration of $6.25 \mu \mathrm{g} / \mathrm{mL}$. a Confocal images (merged images of dead/live bacteria) showed the inhibitory effects of D25 on S. mutans biofilms (Green, live bacteria, SYTO9; red, dead bacteria, PI). Images were taken at $63 \times$ magnification. b Quantification analysis of biomass were evaluated with Comstat 2. * Differences were statistically significant when compared with control group $(P<0.05)$. c Architecture of 24 -h $S$. mutans biofilms was documented by scanning electron microscopy. Images were acquired at the magnification of $5000 \times$ and $20,000 \times$. d The morphological changes of single bacterial cell in biofilms were recorded via atomic force microscopy. White arrows represented $S$. mutans cells

pockets and binding affinity (Baig et al. 2016; Ochoa et al. 2017; Rivera-Pérez et al. 2019). The crystal structure of C123 segment is highly conservative and nearly identical to all S. mutans strains, but heterogeneous compared with other oral streptococci in structural superpositions, which correspond to unique electrostatic surfaces and recognition properties, and subtle changes appeared in structural properties would ultimately result in the

\section{(See figure on next page.)}

Fig. 6 Effects of D25 on bacterial amyloid fibrils. Fluorescence intensity of free-floating bacterial cells and biofilms were utilized to document effects of D25 on amyloid fibrils. a free-floating bacterial cells. $\mathbf{b}$ biofilms. Data were presented as mean \pm standard deviations from three independent experiments. NS differences were not statistically significant when compared with control group $(P<0.05)$. TEM (transmission electron microscopy) images of amyloid fibrils in $\mathbf{c}$ free-floating bacterial cells and $\mathbf{d}$ biofilms were recorded in the presence or absence of D25. White arrows represented amorphous aggregates and red arrows represented amyloid fibrils. e Free amyloid fibrils and single bacterial cell without obvious amyloid fibrils around were visualized in biofilms by TEM images 


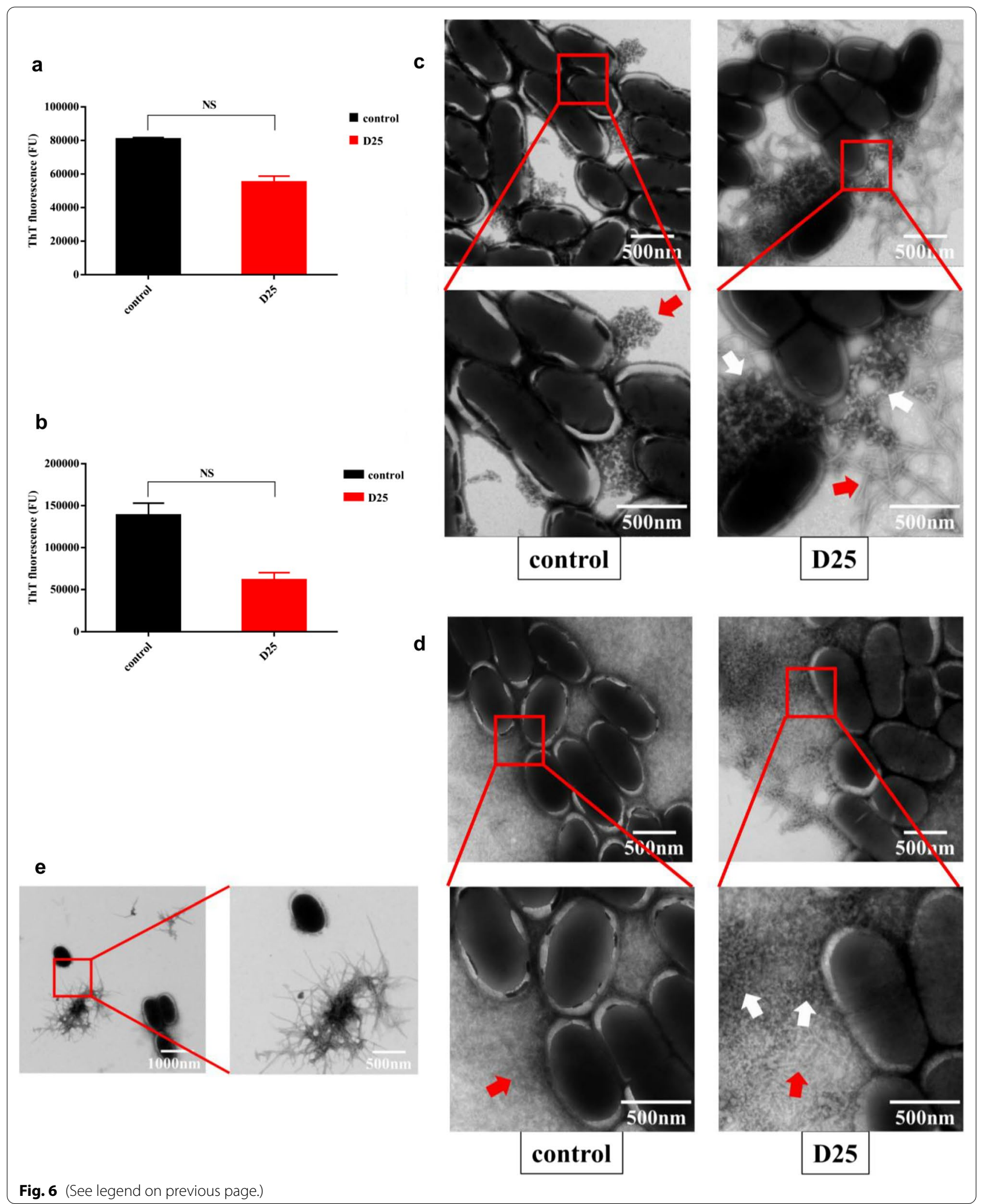




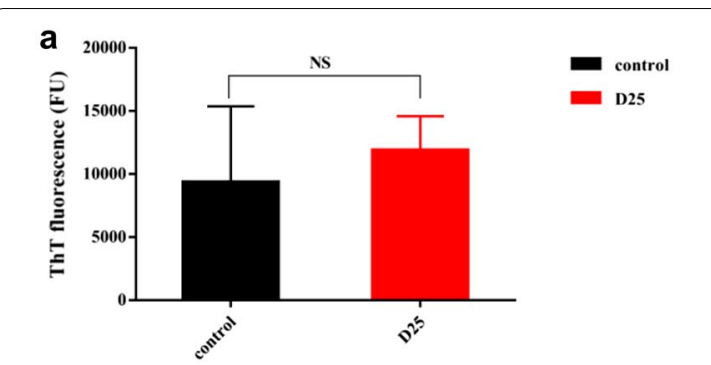

b
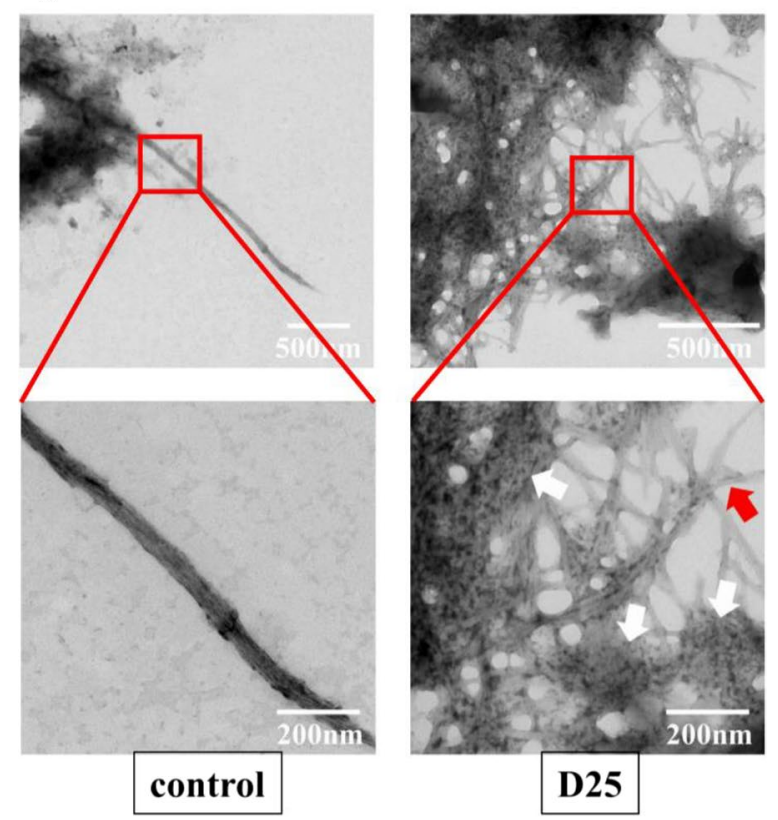

Fig. 7 Effects of D25 on purified proteins. a Fluorescence intensity of purified $\mathrm{C} 123$ were tested via ThT assays. Values were obtained from three independent experiments and shown as mean \pm standard deviations. NS differences were not statistically significant when compared with control group $(P<0.05)$. $\mathbf{b}$ TEM images of amorphous aggregates formed by $\mathrm{C} 123$ in vitro. Typical fibrous structures could be found in control group. Only in D25 group, amorphous aggregates were obvious with long stem amyloid fibrils. White arrows represented amorphous aggregates and red arrows represented amyloid fibrils

distinct characteristics of binding (Larson et al. 2011; Nylander et al. 2011; Esberg et al. 2012, 2017; Yang et al. 2019; Schormann et al. 2021). Therefore, by means of different binding ability, we could select small molecules with high selectivity on specific targets.

We could rationalize that D25 inhibited biofilm formation via amyloid-dependent way. We found that effects of D25 on ThT fluorescence in free-floating bacterial cells, biofilms and purified C123 were not significant compared with control group. Nevertheless, morphological changes were obvious in TEM images. It has been highlighted the importance of TEM to confirm amyloid formation owing

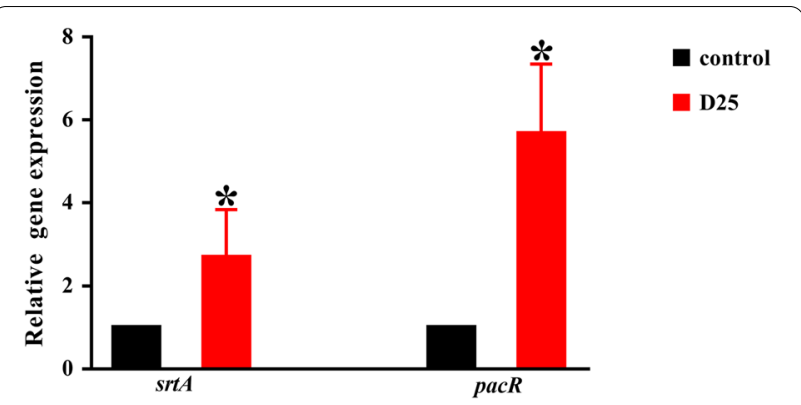

Fig. 8 Effects of D25 on the expression of P1 related genes (srt $A$ and $p a c R$ genes). The results from real-time reverse

transcription-quantitative PCR were calculated by the $2^{-\triangle \Delta C T}$ method. All results were shown as mean \pm standard deviations from three independent experiments. ${ }^{*}$ Differences were statistically significant when compared with control group $(P<0.05)$

to non-specific characteristics of dye-uptake assays (Besingi et al. 2017). Hereinto, the presence of amorphous aggregates were noticeable in response to D25. Amorphous aggregates is the other type of aberrant aggregates present in disordered process, where amyloidogenic proteins stack in a random way rather than form amyloid fibrils (Stranks et al. 2009; Yoshimura et al. 2012). In some circumstances, monomers which favor oligomerization other than fibrillization would tend to form amorphous aggregates, and conformational changes would in turn lead to a greater hydrophobic surface, promote self-tapping process and ultimately benefit in fibrillization (Necula et al. 2007; Stranks et al. 2009; Yoshimura et al. 2012; Vetri and Foderà 2015). The occurrence of mature amyloid fibrils around amorphous aggregates was a corroborative evidence showing their nucleation effects (Stranks et al. 2009; Yoshimura et al. 2012; Vetri and Foderà 2015). Therefore, we can explain that due to a feedback mechanism, amorphous aggregates ultimately lead to formation of amyloid fibrils in $S$. mutans biofilms visualized in TEM images shown in Fig. 7b (Vetri and Foderà 2015). Even though, we are still unable to demonstrate that D25 had no impacts on production of amyloid fibrils based on ThT data. The fluorescence characteristics of amorphous aggregates formed in this study were still puzzling, thus we could not eliminate their effects on ThT uptake. Further exploration is urgent and necessary to detailly evaluate physical and biological properties of amorphous aggregates. In all, we can conclude that D25 induced the formation of amorphous aggregates, which would finally interfere the formation of $S$. mutans biofilms.

In this study, C3 segment seems to be feasible as antiamyloid target. C3 segment is foundation between C123-P1 interactions which corresponds to connections between amyloid fibrils and cell surface (Rivière et al. 
2020). The interactions were found to be attenuated due to the presence of D25, which prompted formation of amorphous aggregates and liberation of amyloid fibrils. Amorphous aggregates tended to show weaker interactions with cell surface as depicted in TEM images. Moreover, dissociated fibril clusters and single bacterial cell were found in D25 group, indicating the liberation of amyloid fibrils from cell surface and dissociation of biofilms. Accordingly, these findings reinforce the role of amyloid fibrils in S. mutans biofilms that they would account for stability of matrix scaffold (Besingi et al. 2017). It coincides with amyloid fibrils in B. subtilis and $S$. aureus biofilms that have been proposed to provide structural integrity and assist in formation of biofilms (Romero et al. 2010; Taglialegna et al. 2016). To detail, we can rationalize that D25 could impact C3-A3VP1 interactions to destroy the integrity of amyloid scaffold, which would ultimately result in diminished biofilm formation.

As far as molecular mechanism was concerned, we analyzed the transcription level of several amyloid related genes quantitatively. A large number of data suggest that bacterial cells interact or respond to a variety of genes when they are influenced with external stimulus (Wen et al. 2006). Amyloid formation was firmly related to $s r t A$ gene and $p a c R$ gene. Of note, $s r t A$ gene mediates the activity of sortase to regulate the linkage of cell surface proteins to bacterial cell walls (Li et al. 2013). Without enough functional sortase, P1 could not anchor to cell walls and form amyloid fibrils (Oli et al. 2012; Li et al. 2013). In addition, pacR regulates the production of surface proteins $\mathrm{P} 1$, which is involved in the formation of amyloid fibrils (Oli et al. 2012). Based on our results, we could find more expression in $\operatorname{srt} A$ and pacR genes due to the presence of D25. Not surprisingly, the occurrence of amorphous aggregates would result in higher expression levels as the negative feedback regulation to promote production of $\mathrm{P} 1$ and sortase so as to form amyloid fibrils. Consequently, this suggests that D25 would affect amyloid formation in a genetic level.

There are still some limitations in our study. In terms of our results, there are no evidence of interaction sites between D25 and C123, even though by means of molecular docking, we could speculate D25 competed binding sites for C3 with A3VP1 (Rivière et al. 2020; Fig. 4). In addition, D25 would function under more than amyloid-dependent mechanism, as several virulence related genes were also influenced (Additional file 1: Figure S2). Moreover, owing to restricted application time and weak scavenging capacity for mature biofilms, which were found to have no effects on preformed 24-h biofilms at the concentration of 1.56$25 \mu \mathrm{g} / \mathrm{mL}$ and only have effects on pre-formed 4-h biofilms at the concentration of $6.25 \mu \mathrm{g} / \mathrm{mL}$ (Detailed procedure was posted in Materials and Methods part in Additional file 1: Figure S3), we need to modify and develop new antimicrobial drugs based on D25.

In summary, our study demonstrated that C3 could be a feasible target aided in finding potent small molecules. Small molecule D25 impaired biofilm formation by means of inducing formation of amorphous aggregates and impairing the integrity of amyloid scaffold. Hereof, targeting amyloid fibrils is a novel and promising strategy to reduce biofilms and ultimately reduce dental caries.

\section{Abbreviations}

S. mutans: Streptococcus mutans; S. aureus: Staphylococcus aureus; B. subtilis: Bacillus subtilis; S. gordonii: Streptococcus gordonii; S. sanguinis: Streptococcus sanguinis; MOE: Molecular operating environment; $\mathrm{BHI}$ : Brain heart infusion; HGE cells: Human gingival epithelial cells; ThT: Thioflavin T.

\section{Supplementary Information}

The online version contains supplementary material available at https://doi. org/10.1186/s13568-021-01333-2.

Additional file 1: Figure S1. The flowchart of structure-based virtual screening. Figure S2. Effects of compound D25 on the expression of vicR, brpA, comDE, atpD and relA genes. The results from qRT-PCR were obtained with the $2^{-\triangle \triangle C T}$ method. All results were shown as mean \pm standard deviations from three independent experiments. *Differences were statistically significant when compared with control group $(P<0.05)$. Figure S3. Effects of D25 on biofilms at different concentrations and time intervals. a S. mutans biofilms formed after $24 \mathrm{~h}$ were treated with different concentrations of D25. NS differences were not statistically significant when compared with control group. $\mathbf{b}$ Effects of D25 on S. mutans biofilms formed after 4, 8, 16 and $24 \mathrm{~h}$. *Differences were statistically significant when compared with control group $(P<0.05)$. NS differences were not statistically significant when compared with control group. Table S1. Primers used in this study for qRT-PCR to quantify gene expression level. Table S2. Top 99 small molecules selected by targeting C3 segment.

\section{Acknowledgements}

Not applicable.

\section{Authors' contributions}

LH and CD conceived research. LH, CD and CY designed research. CY conducted experiments and analyzed data. CG and CY aided in conducting experiment. CY wrote the manuscript. LH and CD revised the manuscript. All authors read and approved the manuscript.

\section{Funding}

Our study was Funded by the National Natural Science Foundation of China (No. 81970928).

\section{Availability of data and materials}

The datasets generated and analysed during the current study are available from the corresponding author on reasonable request.

\section{Declarations}

Ethics approval and consent to participate

This article does not involve any studies on human participants or animals.

Consent for publication

Not applicable. 


\section{Competing interests}

The authors have no competing interests to declare.

\section{Author details}

${ }^{1}$ Department of Preventive Dentistry, Hospital of Stomatology, Sun Yat-Sen University, Guangzhou, Guangdong, China. ${ }^{2}$ Department of Orthodontics, Hospital of Stomatology, Sun Yat-Sen University, Guangzhou, Guangdong, China. ${ }^{3}$ Guangdong Provincial Key Laboratory of Stomatology, Guanghua School of Stomatology, Sun Yat-Sen University, Guangzhou, Guangdong, China.

Received: 4 December 2021 Accepted: 11 December 2021

Published online: 17 December 2021

\section{References}

Baig MH, Ahmad K, Roy S, Ashraf JM, Adil M, Siddiqui MH, Khan S, Kamal MA, Provaznik I, Choi I (2016) Computer aided drug design: success and limitations. Curr Pharm Design 22:572-581. https://doi.org/10.2174/13816 12822666151125000550

Besingi RN, Wenderska IB, Senadheera DB, Cvitkovitch DG, Long JR, Wen ZT, Brady $L J$ (2017) Functional amyloids in Streptococcus mutans, their use as targets of biofilm inhibition and initial characterization of SMU_63C. Microbiology 163:488-501. https://doi.org/10.1099/mic.0.000443

Blanco LP, Evans ML, Smith DR, Badtke MP, Chapman MR (2012) Diversity, biogenesis and function of microbial amyloids. Trends Microbiol 20:66-73. https://doi.org/10.1016/j.tim.2011.11.005

Bleem A, Francisco R, Bryers JD, Daggett V (2017) Designed alpha-sheet peptides suppress amyloid formation in Staphylococcus aureus biofilms. Npj Biofilms Microbi 3:16. https://doi.org/10.1038/s41522-017-0025-2

Bowen WH, Koo H (2011) Biology of Streptococcus mutans-derived glucosyltransferases: role in extracellular matrix formation of cariogenic biofilms. Caries Res 45:69-86. https://doi.org/10.1159/000324598

Brady $\perp$, Maddocks SE, Larson MR, Forsgren N, Persson K, Deivanayagam CC, Jenkinson HF (2010) The changing faces of Streptococcus antigen I/II polypeptide family adhesins. Mol Microbiol 77:276-286. https://doi.org/ 10.1111/j.1365-2958.2010.07212.x

Burley SK, Bhikadiya C, Bi C, Bittrich S, Chen L, Crichlow GV, Christie CH, Dalenberg K, Di Costanzo L, Duarte JM, Dutta S, Feng Z, Ganesan S, Goodsell DS, Ghosh S, Green RK, Guranovic V, Guzenko D, Hudson BP, Lawson CL, Liang Y, Lowe R, Namkoong H, Peisach E, Persikova I, Randle C, Rose A Rose Y, Sali A, Segura J, Sekharan M, Shao C, Tao YP, Voigt M, Westbrook JD, Young JY, Zardecki C, Zhuravleva M (2021) RCSB Protein Data Bank: powerful new tools for exploring 3D structures of biological macromolecules for basic and applied research and education in fundamental biology, biomedicine, biotechnology, bioengineering and energy sciences. Nucleic Acids Res 49:D437-D451. https://doi.org/10.1093/nar/gkaa1038

Cegelski L, Pinkner JS, Hammer ND, Cusumano CK, Hung CS, Chorell E, Åberg V, Walker JN, Seed PC, Almqvist F, Chapman MR, Hultgren SJ (2009) Smallmolecule inhibitors target Escherichia coli amyloid biogenesis and biofilm formation. Nat Chem Biol 5:913-919. https://doi.org/10.1038/nchembio. 242

Chapman MR, Robinson LS, Pinkner JS, Roth R, Heuser J, Hammar M, Normark S, Hultgren SJ (2002) Role of Escherichia coli curli operons in directing amyloid fiber formation. Science 295:851-855. https://doi.org/10.1126/ science.1067484

Chen D, Cao Y, Yu L, Tao Y, Zhou Y, Zhi Q, Lin H (2019a) Characteristics and influencing factors of amyloid fibers in S. mutans biofilm. AMB Express 9:31. https://doi.org/10.1186/s13568-019-0753-1

Chen S, Song Z, Zhang A (2019b) Small-molecule immuno-oncology therapy: advances, challenges and new directions. Curr Top Med Chem 19:180185. https://doi.org/10.2174/1568026619666190308131805

Chen D, Li J, Pan T, Wu R, Tao Y, Lin H (2021) The broad-spectrum antibiofilm activity of amyloid-forming hexapeptides. Microb Biotechnol 14:656-667. https://doi.org/10.1111/1751-7915.13721

Chong CR, Sullivan DJ (2007) New uses for old drugs. Nature 448:645-646. https://doi.org/10.1038/448645a

Costerton JW, Stewart PS, Greenberg EP (1999) Bacterial biofilms: a common cause of persistent infections. Science 284:1318-1322. https://doi.org/10. 1126/science.284.5418.1318 de Jong W, Wösten HA, Dijkhuizen L, Claessen D (2009) Attachment of Streptomyces coelicolor is mediated by amyloidal fimbriae that are anchored to the cell surface via cellulose. Mol Microbiol 73:1128-1140. https://doi. org/10.1111/j.1365-2958.2009.06838.x

Erskine E, MacPhee CE, Stanley-Wall NR (2018) Functional amyloid and other protein fibers in the biofilm matrix. J Mol Biol 430:3642-3656. https://doi. org/10.1016/j.jmb.2018.07.026

Esberg A, Löfgren-Burström A, Öhman U, Strömberg N (2012) Host and bacterial phenotype variation in adhesion of Streptococcus mutans to matched human hosts. Infect Immun 80:3869-3879. https://doi.org/10.1128/IAI. 00435-12

Esberg A, Sheng N, Marell L, Claesson R, Persson K, Borén T, Strömberg N (2017) Streptococcus mutans adhesin biotypes that match and predict individual caries development. EBioMedicine 24:205-215. https://doi.org/ 10.1016/j.ebiom.2017.09.027

Flemming $\mathrm{H}$, Wingender J (2010) The biofilm matrix. Nat Rev Microbiol 8:623-633. https://doi.org/10.1038/nrmicro2415

Ghislat G, Rahman T, Ballester PJ (2021) Recent progress on the prospective application of machine learning to structure-based virtual screening. Curr Opin Chem Biol 65:28-34. https://doi.org/10.1016/j.cbpa.2021.04.009

Heim KP, Crowley PJ, Long JR, Kailasan S, McKenna R, Brady LJ (2014) An intramolecular lock facilitates folding and stabilizes the tertiary structure of Streptococcus mutans adhesin P1. Proc Natl Acad Sci USA 111:1574615751. https://doi.org/10.1073/pnas.1413018111

Heim KP, Sullan RM, Crowley PJ, El-Kirat-Chatel S, Beaussart A, Tang W, Besing R, Dufrene YF, Brady LJ (2015) Identification of a supramolecular functional architecture of Streptococcus mutans adhesin P1 on the bacterial cell surface. J Biol Chem 290:9002-9019. https://doi.org/10.1074/jbc. M114.626663

Heydorn A, Nielsen AT, Hentzer M, Sternberg C, Givskov M, Ersboll BK, Molin S (2000) Quantification of biofilm structures by the novel computer program COMSTAT. Microbiology 146(Pt 10):2395-2407. https://doi.org/ 10.1099/00221287-146-10-2395

Kimber TB, Chen Y, Volkamer A (2021) Deep learning in virtual screening: recent applications and developments. Int J Mol Sci 22:4435. https://doi. org/10.3390/ijms22094435

Klein MI, Duarte S, Xiao J, Mitra S, Foster TH, Koo H (2009) Structural and molecular basis of the role of starch and sucrose in Streptococcus mutans biofilm development. Appl Environ Microbiol 75:837-841. https://doi. org/10.1128/AEM.01299-08

Larsen P, Nielsen JL, Dueholm MS, Wetzel R, Otzen D, Nielsen PH (2007) Amyloid adhesins are abundant in natural biofilms. Environ Microbiol 9:3077-3090. https://doi.org/10.1111/j.1462-2920.2007.01418.x

Larson MR, Rajashankar KR, Crowley PJ, Kelly C, Mitchell TJ, Brady LJ, Deivanayagam C (2011) Crystal structure of the C-terminal region of Streptococcus mutans antigen I/II and characterization of salivary agglutinin adherence domains. J Biol Chem 286:21657-21666. https://doi.org/10.1074/jbc. M111.231100

Lemos JA, Palmer SR, Zeng L, Wen ZT, Kajfasz JK, Freires IA, Abranches J, Brady $\mathrm{LJ}(2019)$ The biology of Streptococcus mutans. Microbiol Spectr 7:P3-P51. https://doi.org/10.1128/microbiolspec.GPP3-0051-2018

LeVine HR (1999) Quantification of beta-sheet amyloid fibril structures with thioflavin T. Methods Enzymol 309:274-284. https://doi.org/10.1016/ s0076-6879(99)09020-5

Li MY, Huang RJ, Zhou XD, Gregory RL (2013) Role of sortase in Streptococcus mutans under the effect of nicotine. Int J Oral Sci 5:206-211. https://doi. org/10.1038/ijos.2013.86

Loquet A, Saupe SJ, Romero D (2018) Functional amyloids in health and disease. J Mol Biol 430:3629-3630. https://doi.org/10.1016/j.jmb.2018.07.024

Necula M, Kayed R, Milton S, Glabe CG (2007) Small molecule inhibitors of aggregation indicate that amyloid beta oligomerization and fibrillization pathways are independent and distinct. J Biol Chem 282:10311-10324. https://doi.org/10.1074/jbc.M608207200

Nylander A, Forsgren N, Persson K (2011) Structure of the C-terminal domain of the surface antigen SpaP from the caries pathogen Streptococcus mutans. Acta Crystallogr Sect F Struct Biol Cryst Commun 67:23-26. https://doi. org/10.1107/S174430911004443X

Ochoa R, Martínez-Pabón MC, Arismendi-Echeverri MA, Rendón-Osorio WL, Muskus-López CE (2017) In silico search of inhibitors of Streptococcus mutans for the control of dental plaque. Arch Oral Biol 83:68-75. https:// doi.org/10.1016/j.archoralbio.2017.06.027 
Oli MW, Otoo HN, Crowley PJ, Heim KP, Nascimento MM, Ramsook CB, Lipke PN, Brady LJ (2012) Functional amyloid formation by Streptococcus mutans. Microbiology 158:2903-2916. https://doi.org/10.1099/mic.0. 060855-0

Paranjapye N, Daggett V (2018) De novo designed alpha-sheet peptides inhibit functional amyloid formation of Streptococcus mutans biofilms. J Mol Biol 430:3764-3773. https://doi.org/10.1016/j.jmb.2018.07.005

Perov S, Lidor O, Salinas N, Golan N, Tayeb-Fligelman E, Deshmukh M, Willbold D, Landau M (2019) Structural insights into curli CsgA cross-beta fibril architecture inspire repurposing of anti-amyloid compounds as antibiofilm agents. Plos Pathog 15:e1007978. https://doi.org/10.1371/journal. ppat.1007978

Ren Z, Cui T, Zeng J, Chen L, Zhang W, Xu X, Cheng L, Li M, Li J, Zhou X, Li $Y$ (2016) Molecule targeting glucosyltransferase inhibits Streptococcus mutans biofilm formation and virulence. Antimicrob Agents Chemother 60:126-135. https://doi.org/10.1128/AAC.00919-15

Rivera-Pérez WA, Yépes-Pérez AF, Martínez-Pabón MC (2019) Molecular docking and in silico studies of the physicochemical properties of potential inhibitors for the phosphotransferase system of Streptococcus mutans. Arch Oral Biol 98:164-175. https://doi.org/10.1016/j.archoralbio.2018.09. 020

Rivière G, Peng E, Brotgandel A, Brady J, Long JR (2020) Characterization of intermolecular quaternary interactions between discrete segments of the Streptococcus mutans adhesin p1 and their binding to small molecule amyloid inhibitors via NMR spectroscopy. Biophys J 118:182a. https://doi. org/10.1016/j.bpj.2019.11.1111

Romero D, Aguilar C, Losick R, Kolter R (2010) Amyloid fibers provide structural integrity to Bacillus subtilis biofilms. Proc Natl Acad Sci USA 107:22302234. https://doi.org/10.1073/pnas.0910560107

Romero D, Sanabria-Valentin E, Vlamakis H, Kolter R (2013) Biofilm inhibitors that target amyloid proteins. Chem Biol 20:102-110. https://doi.org/10. 1016/j.chembiol.2012.10.021

Saldaña Z, Xicohtencatl-Cortes J, Avelino F, Phillips AD, Kaper JB, Puente JL, Girón JA (2009) Synergistic role of curli and cellulose in cell adherence and biofilm formation of attaching and effacing Escherichia coli and identification of Fis as a negative regulator of curli. Environ Microbiol 11:992-1006. https://doi.org/10.1111/j.1462-2920.2008.01824.x

Scharnow AM, Solinski AE, Wuest WM (2019) Targeting S. mutans biofilms: a perspective on preventing dental caries. Medchemcomm 10:1057-1067. https://doi.org/10.1039/c9md00015a

Schormann N, Purushotham S, Mieher JL, Patel M, Wu H, Deivanayagam C (2021) Structural and functional analysis of the C-terminal region of Streptococcus gordonii SspB. Acta Crystallogr D Struct Biol 77:1206-1215. https://doi.org/10.1107/S2059798321008135

Schwartz K, Syed AK, Stephenson RE, Rickard AH, Boles BR (2012) Functional amyloids composed of phenol soluble modulins stabilize Staphylococcus aureus biofilms. Plos Pathog 8:e1002744. https://doi.org/10.1371/journal. ppat. 1002744

Schwartz K, Ganesan M, Payne DE, Solomon MJ, Boles BR (2016) Extracellular DNA facilitates the formation of functional amyloids in Staphylococcus aureus biofilms. Mol Microbiol 99:123-134. https://doi.org/10.1111/mmi. 13219

Sharma S, Lavender S, Woo J, Guo L, Shi W, Kilpatrick-Liverman L, Gimzewski JK (2014) Nanoscale characterization of effect of L-arginine on Streptococcus mutans biofilm adhesion by atomic force microscopy. Microbiology 160:1466-1473. https://doi.org/10.1099/mic.0.075267-0

Stranks SD, Ecroyd H, Van Sluyter S, Waters EJ, Carver JA, von Smekal L (2009) Model for amorphous aggregation processes. Phys Rev E Stat Nonlin Soft Matter Phys 80:51907. https://doi.org/1 0.1103/PhysRevE.80.051907

Taglialegna A, Navarro S, Ventura S, Garnett JA, Matthews S, Penades JR, Lasa I, Valle J (2016) Staphylococcal bap proteins build amyloid scaffold biofilm matrices in response to environmental signals. Plos Pathog 12:e1005711. https://doi.org/10.1371/journal.ppat.1005711

Vetri V, Foderà V (2015) The route to protein aggregate superstructures: particulates and amyloid-like spherulites. Febs Lett 589:2448-2463. https:// doi.org/10.1016/j.febslet.2015.07.006

Wen ZT, Baker HV, Burne RA (2006) Influence of BrpA on critical virulence attributes of Streptococcus mutans. J Bacteriol 188:2983-2992. https://doi. org/10.1128/JB.188.8.2983-2992.2006

Yang J, Deng D, Brandt BW, Nazmi K, Wu Y, Crielaard W, Ligtenberg A (2019) Diversity of SpaP in genetic and salivary agglutinin mediated adherence among Streptococcus mutans strains. Sci Rep 9:19943. https://doi.org/10. 1038/s41598-019-56486-9

Yoshimura Y, Lin Y, Yagi H, Lee YH, Kitayama H, Sakurai K, So M, Ogi H, Naiki H, Goto Y (2012) Distinguishing crystal-like amyloid fibrils and glass-like amorphous aggregates from their kinetics of formation. Proc Natl Acad Sci USA 109:14446-14451. https://doi.org/10.1073/pnas.1208228109

Zhang C, Kuang X, Zhou Y, Peng X, Guo Q, Yang T, Zhou X, Luo Y, Xu X (2019) A novel small molecule, ZY354, inhibits dental caries-associated oral biofilms. Antimicrob Agents Chemother 63:e2414-e2418. https://doi.org/ 10.1128/AAC.02414-18

Zorn KM, Sun S, McConnon CL, Ma K, Chen EK, Foil DH, Lane TR, Liu LJ, El-Sakkary N, Skinner DE, Ekins S, Caffrey CR (2021) A machine learning strategy for drug discovery identifies anti-schistosomal small molecules. Acs Infect Dis 7:406-420. https://doi.org/10.1021/acsinfecdis.0c00754

\section{Publisher's Note}

Springer Nature remains neutral with regard to jurisdictional claims in published maps and institutional affiliations.

\section{Submit your manuscript to a SpringerOpen ${ }^{\circ}$ journal and benefit from:}

- Convenient online submission

- Rigorous peer review

- Open access: articles freely available online

- High visibility within the field

- Retaining the copyright to your article

Submit your next manuscript at $\boldsymbol{\nabla}$ springeropen.com 